\title{
Candida interface keratitis after deep anterior lamellar keratoplasty treated with early penetrating keratoplasty: case report
}

\section{Queratitis de la interfase por cándida después de una queratoplastia lamelar anterior profunda tratada con queratoplastia penetrante temprana: Reporte de un caso}

\author{
Ricardo Navarro-Saucedo ${ }^{1, *}$, Héctor G. Cámara-Castillo², César Hernández-Chavarría1 , and \\ Juan J. Marx-Blanquer ${ }^{1}$ \\ ${ }^{1}$ Departamento de Oftalmología, Facultad de Medicina, Universidad Autónoma de Yucatán; ${ }^{2}$ Clínica de Mérida. Mérida, Yuc., Mexico
}

\begin{abstract}
Objective: To report a case of interface keratitis caused by Candida after deep anterior lamellar keratoplasty (DALK) with small lesions, treated with early penetrating keratoplasty. Observations: The case is about a 37-year-old male treated with DALK on his right eye for keratoconus. Few days after the procedure, the donor rim culture was positive for Candida. Prophylaxis did not prevent the development of infection after three months. Topical and systemic antifungal therapy was not effective. Despite the small size of the lesions, we performed penetrating keratoplasty (PK). Microbiologic and histopathologic reports confirmed Candida glabrata interface keratitis. Six months after PK, the cornea remains clear with a best-corrected visual acuity of 20/30. Conclusions and importance of the case: Our case shows that early PK, despite the small size of the lesions, improves outcomes in Candida interface keratitis after DALK. A positive donor rim culture is useful for early decision making.
\end{abstract}

Key words: Candida. Interface. Fungal. Keratitis. Deep anterior lamellar keratoplasty.

\section{Resumen}

Objetivo: Reportar un caso de queratitis de la interfase por cándida después de una queratoplastia lamelar anterior profunda (DALK) con lesiones pequeñas, tratada con queratoplastia penetrante temprana. Observaciones: Paciente de sexo masculino de 37 años tratado con DALK en el ojo derecho por queratocono. Pocos días después del procedimiento, el cultivo del rodete donador fue positivo para cándida. La profilaxis no evitó el desarrollo de la infección 3 meses después. Los antifúngicos tópicos y sistémicos no fueron efectivos. Aunque las lesiones eran pequeñas, se realizó queratoplastia penetrante (QPP). Los reportes microbiológico e histopatológico confirmaron queratitis de la interfase por Candida glabrata. A los 6 meses posquirúrgicos, la córnea permanece clara y la capacidad visual es de 20/30. Conclusiones e importancia del caso: Nuestro caso muestra que la QPP temprana, a pesar del pequeño tamaño de las lesiones, optimiza los resultados en la queratitis de la interfase por cándida después de DALK. Un cultivo de rodete donador positivo sirve para tomar la decisión oportuna.

Palabras clave: Cándida. Interfase. Fúngica. Queratitis. Queratoplastía lamelar anterior profunda.

\section{Correspondence:}

${ }^{*}$ Ricardo Navarro-Saucedo

$36^{\text {th }}$ street \#242A, dept. 4, between 27th and 29th street

Col. García Ginerés

Date of reception: 04-11-2019

Date of acceptance: 09-01-2020

E-mail: dr.ricardonavarro.s@gmail.com 2604-1731/@ 2020 Sociedad Mexicana de Oftalmología. Published by Permanyer. This is an open access article under the CC BY-NC-ND license (http://creativecommons.org/licenses/by-nc-nd/4.0/). 


\section{Introduction}

The Eye Bank Association of America (EBAA) reports a rate of fungal infections (keratitis and endophthalmitis) after anterior lamellar keratoplasty of $0.52 \%$ in a 4-year period. Candida species are the most frequent pathogens associated with infection after DALK'. In areas with a high risk of fungal infections, it is recommended to perform a fungal culture of the donor rim due to its high positive predictive value $(10.7 \%)^{2}$. There are few cases reported of Candida interface keratitis after DALK ${ }^{3-9}$. Such low casuistry makes it difficult to standardize treatment. Usually, empirically treatment with topical and systemic antifungal agents is initiated in highly suspicious cases. Interface irrigation with antifungals was successful in one case ${ }^{4}$, but in most cases it is associated with Descemet membrane rupture ${ }^{4-7}$. Here we report our experience with a case of Candida interface keratitis after DALK. We obtained informed consent to publish the results.

\section{Case presentation}

This case is about a 37-year-old male with keratoconus, who underwent DALK of the right eye without complications. Five days after DALK, the donor corneoscleral rim culture was positive for Candida glabrata. Therefore, we started prophylaxis based on topical voriconazole $1 \%$ four times a day, as well as oral fluconazole $400 \mathrm{mg}$ daily initially and then $200 \mathrm{mg}$ daily for 2 months.

Three months after keratoplasty, we noticed two white $1 \mathrm{~mm}$ infiltrates on the superior nasal sector of the peripheral donor-host interface, without inflammation signs. Thus, we restarted antifungals. Fifteen days later, the patient presented to the clinic with a complaint of ocular redness for 3 days. Slit-lamp exam showed stromal edema ++ , Descemet folds, the persistence of the same corneal infiltrates, and three new infiltrates in the deep interface (Figure 1), as well as anterior chamber cells $1+$.

There was no response to antifungals and the clinical features were similar to a stromal rejection, so the patient was treated with topical steroids. Redness and inflammation improved, but all the infiltrates persisted. Anterior segment optical coherence tomography (OCT) confirmed the location of the lesions at the deep interface (Figure 2). The history of a positive donor rim culture, the clinical suspicion due to the features of the infiltrates, the imaging by anterior segment OCT, and the bad prognosis associated with infections that

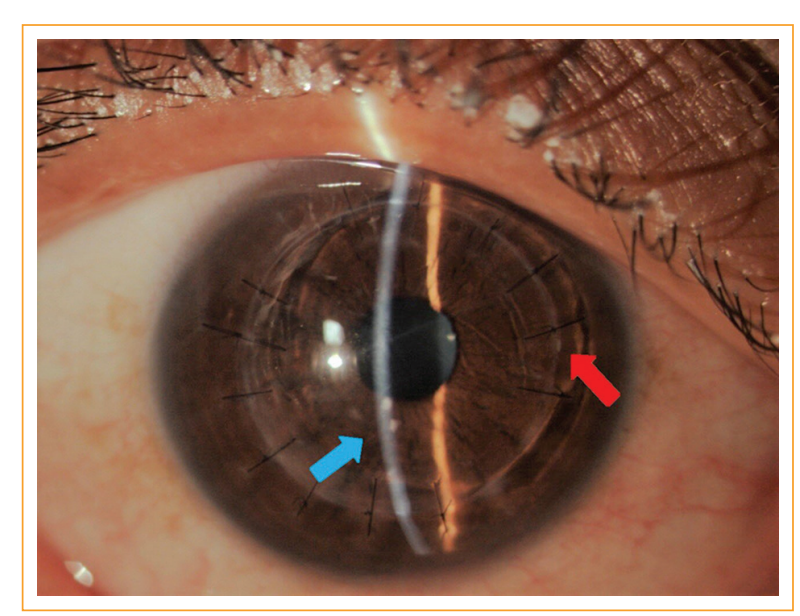

Figure 1. Slit-lamp photograph of paracentral white infiltrates at the deep (blue arrow) and peripheral (red arrow) graft-host interface just before penetrating keratoplasty.

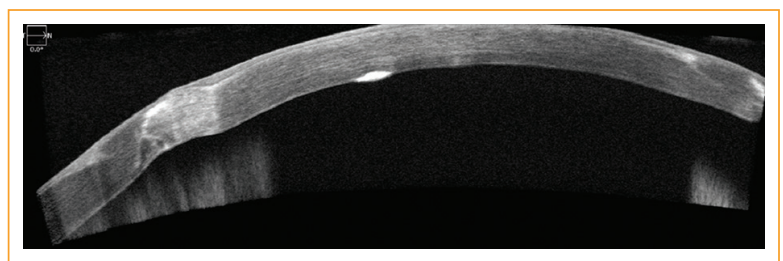

Figure 2. High definition anterior segment optical coherence tomography showing a hyperreflective lesion between the Descemet membrane and the deep corneal stroma.

progress, led us to perform a penetrating keratoplasty (PK) with an $8.25 \mathrm{~mm}$ trephine $(0.5 \mathrm{~mm}$ larger than the trephine used for DALK). We sent the excised donor button for culture and histopathologic assessment (Figure 3), and the diagnosis of Candida glabrata keratitis was confirmed, consistent with the initial culture.

Six months after surgery the corneal graft remains clear with no recurrent infection, and the patient has a best-corrected visual acuity of 20/30 with 2 remaining sutures.

\section{Discussion}

There is evidence that prophylaxis with antimycotics in cases of a positive donor rim fungal culture, may reduce the incidence of post-keratoplasty keratitis ${ }^{10}$. In our case, it did not prevent the development of the infection, but having the result of the culture was essential to make the timely decision of performing a PK. 


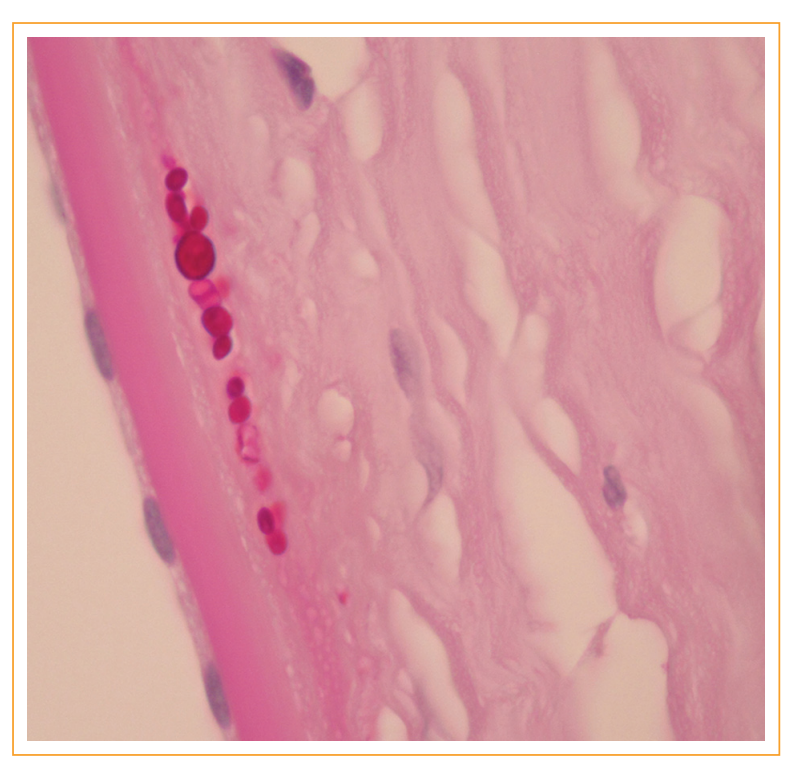

Figure 3. Photomicrograph of PAS-positive yeast-like structures in the deep interface, next to Descemet membrane, with a 100X magnification.

PAS: Periodic Acid-Schiff.

The time of onset of fungal interface keratitis after DALK ranges from 4 days to 4 months $^{9}$. In our case, the clinical infection started at 3 months.

Treatment with only topical and systemic antifungals was not effective in the reported cases of Candida interface keratitis after $\mathrm{DALK}^{6,7}$, including ours. The location of the infection deep in the cornea may explain the high failure rate of this treatment.

One of the main differential diagnoses of interface keratitis, as considered in 5 previous cases $^{3-5,8}$, is epithelial ingrowth into the interface. We also considered it when observing the first infiltrates without inflammation, but when the first signs of inflammation appeared, our main differential diagnosis was stromal rejection. At that time, we treated our patient with topical steroids as there was no initial response to antifungals. Finally, we returned to our initial suspicion of fungal keratitis due to an incomplete response to steroids. The definitive treatment for our patient was PK, consistent with most of the other reported cases ${ }^{4-8}$. We decided not to irrigate the interface due to the high rate of Descemet membrane rupture. In the review by Fontana et al., PK was the most effective treatment. They recommend PK whenever there are signs of spreading despite antifungals ${ }^{9}$.

\section{Conclusions}

Based on the results, a positive donor rim culture for Candida may justify PK with extended trephination at early stages of the infection, when the lesions are still small. This therapeutic approach seems to achieve a faster resolution of the infection and optimizes visual outcomes.

\section{Acknowledgments}

Abelardo A. Rodríguez-Reyes, MD Chief of the Ophthalmic Pathology Service of APEC, Hospital "Dr. Luis Sánchez Bulnes", for the histopathologic study and photomicrographs.

\section{Conflicts of interest}

The authors declare no conflicts of interest.

\section{Ethical disclosures}

Protection of human and animal subjects. The authors declare that the procedures followed were in accordance with the regulations of the relevant clinical research ethics committee and with those of the Code of Ethics of the World Medical Association (Declaration of Helsinki).

Confidentiality of data. The authors declare that they have followed the protocols of their work center on the publication of patient data.

Right to privacy and informed consent. The authors have obtained the written informed consent of the patients or subjects mentioned in the article. The corresponding author is in possession of this document.

\section{References}

1. Aldave AJ, DeMatteo J, Glasser DB, Tu EY, lliakis B, Nordlund ML, et al. Report of the Eye Bank Association of America Medical Advisory Board Subcommittee on Fungal Infection After Corneal Transplantation. Cornea. 2013;32(2):149-154

2. Kiatos E, Armstrong JJ, Hutnik CM, Tsioros SM, Malvankar-Mehta MS, Hodge WG. The value of corneoescleral rim culture in keratoplasty: a systematic review and cost-effectiveness analysis. Clinicoecon Outcomes Res 2017;9:459-474

3. Sedaghat MR, Hosseinpoor SS. Candida albicans interface infection after deep anterior lamellar keratoplasty. Indian J Ophthalmol 2012;60(4):328330 .

4. Bahadir AE, Boskurt TK, Kutan SA, Yanyali CA, Acar S. Candida interface keratitis following deep anterior lamellar keratoplasty. Int Ophthalmol, 2012;32:383-386.

5. Kanavi MR, Forountan AR, Kamel MR, Afsar N, Javadi MA. Candida interface keratitis after deep anterior lamellar keratoplasty: clinical, microbiologic, histopathologic, and confocal microscopic reports. Cornea 2007;26(8), 913-916

6. Wessel JM, Bachmann BO, Meiller R, Kruse FE. Fungal interface keratitis by Candida orthopsilosis following deep anterior lamellar keratoplasty. BMJ case reports. Fuente: URL: https://casereports.bmj.com/content/2013/bcr2012-008361.citation-tools. Consultado el 21 de Julio de 2019.

7. Fontana, L., Parente, G., Di Pede, B., \& Tassinari, G. Candida albicans Interface Infection After Deep Anterior Lamellar Keratoplasty. Cornea 2007;26(7):883-885

8. Le Q, Wu D, Li Y, Ji J, Cai R, Xu J. Early-onset Candida glabrata interface keratitis after deep anterior lamellar keratoplasty. Optom Vis Sci 2015:92:e93-6.

9. Fontana L, Moramarco A, Mandarà E, Russello G, lovieno A. Interface infectious keratitis after anterior and posterior lamellar keratoplasty. Clinical features and treatment strategies. $\mathrm{A}$ review. $\mathrm{Br} \mathrm{J}$ Ophthalmol 2018;0:1-8.

10. Vislisel JM, Goins KM, Wagoner MD, Schmidt GA, Aldrich BT, Skeie JM, et al. Incidence and Outcomes of Positive Donor Corneoescleral Rim Fungal Cultures after Keratoplasty. Ophthalmology 2017;124(1):36-42. 